\title{
REVITALISASI NILAI PANCASILA DALAM UPAYA PEMBERANTASAN TINDAK PIDANA DI BIDANG KEPABEANAN DI INDONESIA
}

\author{
Deaf Wahyuni Ramadhani \\ Fakultas Hukum Universitas Bung Hatta \\ email: deaf.wahyuni@yahoo.com
}

Naskah diterima: 12/04/2017 revisi: 27/04/2017 disetujui: 27/04/2017

\begin{abstract}
Abstrak
Kegiatan ekspor dan impor sangat berhubungan erat dengan tindak pidana penyelundupan. Kebijakan pemerintah terkait bidang kepabeanan yaitu dengan disyahkannya Undang-undang No. 10 Tahun 1995 tentang Kepabeanan yang kemudian dirubah dengan Undang-undang No. 17 Tahun 2006 (UU Kepabeanan), merupakan sikap antisipatif yang menjangkau dimensi strategi, substantif, dan esensial di bidang perdagangan internasional, yang diharapkan mampu menghadapi tantangan globalisasi dan perdagangan internasional. Tujuan dari penulisan artikel ini adalah mengkaji apakah arti penting revitalisasi nilai Pancasila dalam upaya pemberantasan tindak pidana di bidang kepabeanan di Indonesia?. Kajian dilakukan menggunakan metodologi kualitatif dengan pendekatan normatif dan studi kepustakaan yang bersumber dari, peraturan perundang-undangan, buku, dan artikel jurnal ilmiah. Setelah melalui dari hasil kajian maka ditemukan suatu kesimpulan bahwa masih tingginya angka penyelundupan di Indonesia merupakan suatu gambaran bahwa bidang ekonomi di Indonesia masih miskin nilai sehingga harus ditata dengan politik nilai keadilan sosial. Hukum memiliki tugas yang berat untuk menanamkan pemahaman pada pengusaha dan aparat akan nilai keadilan sosial. Dengan menjadikan nilai keadilan sosial sebagai karakter bagi mereka.
\end{abstract}

Kata kunci: 1 atau lebih kata atau frase yang penting, spesifik, atau representatif bagi artikel ini

\section{REVITALIZATION OF PANCASILA VALUES EFFORTS IN COMBATING CRIME IN CUSTOMS AFFAIRS IN INDONESIA Abstract}

Export and import activities are very closely linked to the crime of smuggling. Government policy related to customs matters, namely the legalization UU No 101995 on Customs which was later amended by UU No. 17 2006, an anticipatory attitude that spans the dimensions of the strategy, substantive, and essential in the field of international trade, which is expected to be able to face the challenges of globalization and international trade. The purpose of writing this article is to examine whether the importance of the revitalization of the Pancasila in efforts to combat crime in the area of customs in Indonesia?. The study was conducted using qualitative methodologies with the normative approach and the study of literature originating from, legislation, books, and scientific journal articles. After going through the results of the study found a conclusion that the high level of smuggling in Indonesia is a picture that economic sector in Indonesia is still poor value and should be set up with the political values of social justice. Laws have a heavy duty to cultivate an understanding of the businessmen and officials of the value of social justice. By making the values of social justice as a character for them

Keywords: one or more word(s) or phrase(s), that it's important, spesific, or representative for the article 


\section{PENDAHULUAN}

Proses globalisasi (Sulistiyono, 2009:25 dan Deliarnov, 2006:201) yang semakin lama semakin intens terjadi memberi implikasi bahwa setiap negara dituntut untuk mengantisipasi dan bisa beradaptasi dengan kecenderungan globalisasi menuju perapatan dunia (compression of the world) yang semakin tanpa batas (borderles) (Adam dan Sambodo, 2008:15). Untuk mengantisipasi saling bersinggungan di bidang ekonomi memerlukan adanya harmonisasi hukum ekonomi lintas negara termasuk kesepakatan mengenai aturan main yang berlaku (Simanjuntak, 2008:13). Seiring dengan perkembangan ekonomi dunia maka berbagai organisasi di bidang ekonomi bermunculan seperti World Trade Organization (WTO) dengan agenda General Agreement on Trade (GAT). Sedangkan di tingkat Asia Tenggara terdapat Asean Free Trade Agreement (AFTA) yang merupakan bagian dari kebijakan Masyarakat Ekonomi Asean (MEA).

Indonesia sebagai negara yang telah meratifikasi persetujuan internasional di bidang perdagangan harus mematuhi segala ketentuan yang berlaku bagi semua negara anggota dengan segala konsekuensinya. Keadaan ini menempatkan Indonesia untuk benar-benar mengikuti dan mengembangkan hukum ekonomi internasional terutama dalam pelaksanaan atau penegakan hukumnya. Hal ini berarti bahwa apabila terdapat kekeliruan dalam pengelolaannya maka akan berakibat dirugikannya Indonesia dalam perdagangan internasional atau perdagangan bebas tersebut, bahkan dampaknya tidak hanya menyangkut para pihak dalam perjanjian bisnis internasional tersebut, melainkan juga rakyat Indonesia secara keseluruhan.

Berkomitmen untuk menerima keberadaan globalisasi ekonomi berarti bahwa bangsa Indonesia siap dengan segala konsekuensi yang ditimbulkannya. Baik dampak positif maupun dampak negatif. Adapun dampak positif dari globalisasi ekonomi diantaranya (Alicezah, 2008). produksi global dapat ditingkatkan; meningkatkan kemakmuran masyarakat dalam suatu negara; meluaskan pasar untuk produk dalam negeri; dapat memperoleh lebih banyak modal dan teknologi yang lebih baik; dan menyediakan dana tambahan untuk pembangunan ekonomi.

Selain itu, globalisasi ekonomi juga mempunyai dampak yang negatif bagi kehidupan masyarakat Indonesia diantaranya: menghambat pertumbuhan sektor industri; memperburuk neraca pembayaran; dan sektor keuangan semakin tidak stabil.

Sedangkan menurut Rowland B.F. Pasaribu dampak positif dan negatif dari globalisasi dapat dilihat pada tabel 1 berikut. 
Citizenship Jurnal Pendidikan Pancasila dan Kewarganegaraan Vol 5 No 1 April 2017, hal 32-41 Avaliable online at : http://e-journal.unipma.ac.id/index.php/citizenship p-ISSN: 2302-433Xp e-ISSN 2579-5740

Tabel 1. Dampak Positif dan negatif globalisasi

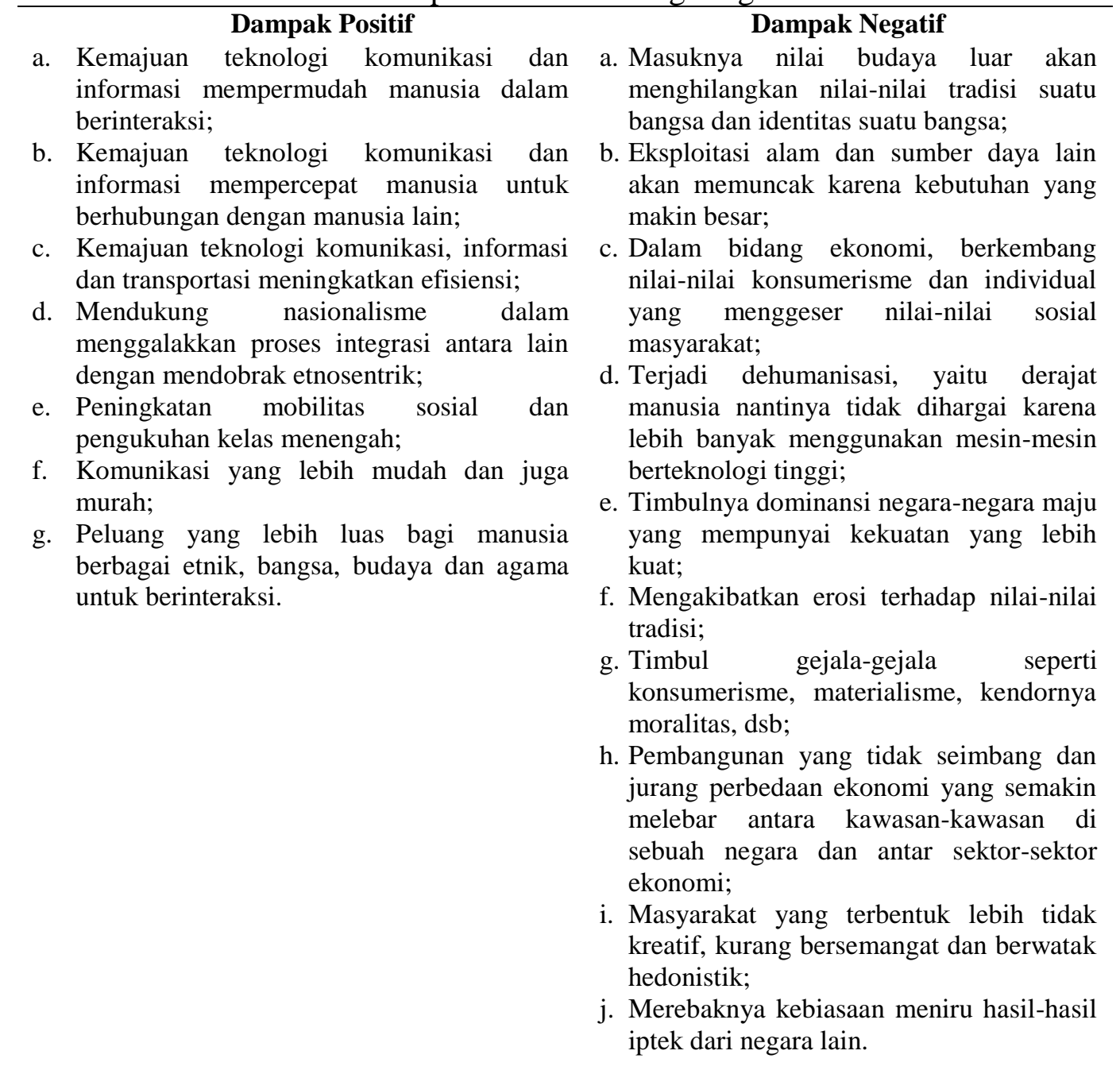

tabel 2. Sedangkan bentuk grafik neraca

Aktivitas ekspor impor tercermin dalam neraca perdagangan (Wikipedia) suatu negara. Kebijakan liberalisasi perdagangan yang berusaha untuk menghilangkan hambatan perdagangan dapat meningkatkan ekspor namun di lain pihak juga dapat meningkatkan impor. Suatu negara bertujuan untuk memiliki neraca perdagangan yang surplus atau ekspor lebih besar daripada impor. Dengan demikian, liberalisasi perdagangan akan berpengaruh terhadap neraca perdagangan yakni pertumbuhan ekspor dan impor. Pertumbuhan ekspor dan impor inilah yang menentukan necara perdagangan surplus atau defisit (Nongsina dan Hutabarat).

Berikut data neraca perdagangan Indonesia periode 2003-2013 tersaji pada perdagangan Indonesia tahun 2013-2013 dari data yang diuraikan di atas tersedia pada gambar 1, sedangkan surplus/defisit neraca perdagangan Indonesia tahun 20032013 dapat dilihat pada gambar 2 berikut ini. 
Citizenship Jurnal Pendidikan Pancasila dan Kewarganegaraan Vol 5 No 1 April 2017, hal 32-41 Avaliable online at : http://e-journal.unipma.ac.id/index.php/citizenship p-ISSN: 2302-433Xp e-ISSN 2579-5740

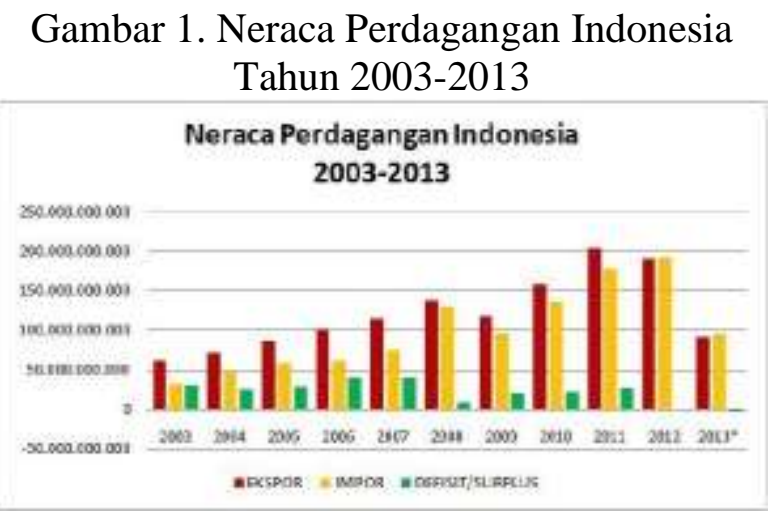

Gambar 2. Grafik Surplus/Defisit Neraca Perdagangan Indonesia Tahun 2003-2013

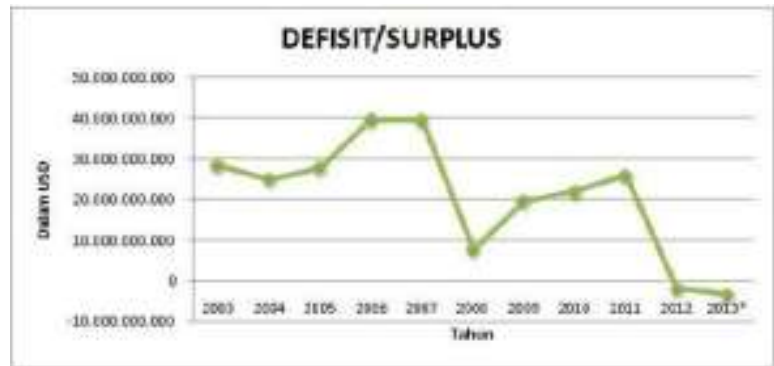

Tabel 2. Neraca Perdagangan Indonesia Tahun 2003-2013

\begin{tabular}{lrrr} 
Tahun & \multicolumn{1}{c}{ Ekspor } & \multicolumn{1}{c}{ Impor } & \multicolumn{1}{c}{ Defisit/Surplus } \\
2003 & 61.058 .246 .995 & 32.550 .684 .286 & 28.507 .562 .709 \\
2004 & 71.584 .608 .796 & 46.524 .531 .358 & 25.060 .077 .438 \\
2005 & 85.659 .952 .615 & 57.700 .882 .616 & 27.959 .069 .999 \\
2006 & 100.798 .624 .280 & 61.065 .465 .536 & 39.733 .158 .744 \\
2007 & 114.100 .890 .751 & 74.473 .430 .118 & 39.627 .460 .633 \\
2008 & 137.020 .424 .402 & 129.197 .306 .224 & 7.823 .118 .178 \\
2009 & 116.510 .026 .081 & 96.829 .244 .981 & 19.680 .781 .100 \\
2010 & 157.779 .103 .470 & 135.663 .284 .048 & 22.115 .819 .422 \\
2011 & 203.496 .620 .060 & 177.435 .555 .736 & 26.061 .064 .324 \\
2012 & 190.031 .845 .244 & 191.691 .001 .109 & -1.659 .155 .865 \\
$2013 *$ & 91.068 .762 .794 & 94.410 .645 .297 & -3.341 .882 .503 \\
\hline
\end{tabular}

Sumber: bps.go.id

Keterangan:

*angka sementara (Bulan Januari-Juni).

Kegiatan ekspor dan impor sangat berhubungan erat dengan tindak pidana penyelundupan (Marpaung, 1991:9). Tindakan penyelundupan menjadi perhatian karena dilakukan secara kasat mata. Sebagian besar dan diketahui adanya aksi penyelundupan itu bahkan barang-barang tersebut diperdagangkan secara bebas. Istilah "penyelundupan", "menyelundup" sebenarnya bukan istilah yuridis. Penyelundupan merupakan pengertian gejala sehari-hari dimana seseorang secara diam-diam atau sembunyi-sembunyi memasukkan atau mengeluarkan barang- 
barang ke atau dari dalam negeri dengan latar belakang tertentu (Chibro, 1992:13).

Hampir setiap hari pemberitaan menyuguhkan mengenai maraknya penyelundupan yang terjadi di berbagai daerah baik yang masuk maupun keluar dari Indonesia. Penyelundupan ini sudah pada taraf yang memprihatinkan, karena terjadi untuk setiap aspek, mulai dari penyelundupan kendaraan bermotor, satwa liar, elektronik, hasil hutan, bahan bakar minyak (BBM) bahkan sampai penyelundupan bahan pokok seperti beras dan gula.

Kebijakan pemerintah terkait bidang kepabeanan yaitu dengan disyahkannya Undang-undang No. 10 Tahun 1995 tentang Kepabeanan yang kemudian dirubah dengan Undang-undang No. 17 Tahun 2006 (selanjutnya disebut UU Kepabeanan), merupakan sikap antisipatif yang menjangkau dimensi strategi, substantif, dan esensial di bidang perdagangan internasional, yang diharapkan mampu menghadapi tantangan globalisasi dan perdagangan internasional.

Secara umum pelanggaran pabean sebagaimana dimaksud dalam Konvensi Tokyo dikelompokkan atas dua kelompok, yakni: (1) pelanggaran ketentuan administrasi; dan (2) pelanggaran ketentuan pidana.

Sedangkan menurut WCO Handbook for Commercial Fraud Investigators dipilah menjadi enam belas tipe pelanggaran utama di bidang kepabeanan, yaitu: penyelundupan; uraian barang tidak benar; pelanggaran nilai barang; pelanggaran negara asal barang; pelanggaran fasilitas keringanan bea masuk atas barang yang diolah; pelanggaran impor sementara; pelanggaran perizinan impor/ekspor; pelanggaran transit barang; pemberitahuan jumlah muatan barang tidak benar; pelanggaran tujuan pemakaian; pelanggaran spesifikasi barang dan perlindungan konsumen; barang melanggar hak atas kekayaan intelektual; transaksi gelap; pelanggaran pengembalian bea; usaha fiktif; dan likuidasi palsu.

Garis kebijakan umum yang menjadi landasan sekaligus tujuan politik hukum di Indonesia tercantum dalam pernyataan singkat pada perumusan Pembukaan UUD 1945, yakni "melindungi segenap bangsa Indonesia dan memajukan kesejahteraan umum berdasarkan Pancasila". Dasar politik hukum inilah yang menjadi landasan dan tujuan setiap usaha pembaruan hukum, termasuk pembaruan di bidang hukum pabean dan kebijakan penanggulangan pelanggaran di bidang kepabeanan (customs fraud) (Sutarto, 2010:3).

Pemberantasan tindak pidana penyelundupan dapat dipandang dari dua sisi, yakni menyelamatkan devisa, yang dalam pembangunan yang sedang dilaksanakan sekarang dibutuhkan baik untuk pembayaran barang-barang yang belum dapat diproduksi di Indonesia, maupun pembayaran tenaga ahli dari luar negeri, dan lain-lain disatu sisi dan melindungi pertumbuhan industri yang sedang berkembang, yang masih kurang mampu bersaing dengan produksi luar negeri, sehingga dapat diharapkan mengurangi pengangguran yang saat ini merupakan masalah dalam peningkatan penghasilan nasional disisi lain (Marpaung, 1991:9, Sutarto, 1999:189, dan Bayu, 2014:4).

Selama tahun 2008 DJBC telah melakukan penindakan terhadap 2,109 kasus penyelundupan dengan kerugian keuangan negara sebesar 253,936 Miliar. Berikut pada tabel 2 dapat dilihat rincian dari kasus tersebut .

Sedangkan pada tahun 2009 angka penyelundupan ini meningkat tajam, dimana telah dilakukan penindakan terhadap 2,093 kasus penyelundupan dan negara dirugikan sebesar 523,742 miliar. Berikut rinciannya tersaji pada tabel 3 dan 4 . 
Citizenship Jurnal Pendidikan Pancasila dan Kewarganegaraan Vol 5 No 1 April 2017, hal 32-41 Avaliable online at : http://e-journal.unipma.ac.id/index.php/citizenship p-ISSN: 2302-433Xp e-ISSN 2579-5740

Tabel 3. Kerugian Negara yang Disebabkan oleh Penyelundupan Tahun 2008

\begin{tabular}{clrr}
\hline No. & \multicolumn{1}{c}{ Jenis Kasus } & \multicolumn{1}{c}{$\begin{array}{c}\text { Jumlah } \\
\text { Kasus }\end{array}$} & $\begin{array}{c}\text { Kerugian Negara } \\
\text { (dalam Milliar Rp) }\end{array}$ \\
\hline 1 & Tekstil dan produk tekstil & 82 & 3,093 \\
2 & Handphone dan aksesoris & 85 & 10,964 \\
3 & Barang lartas* & 852 & 8,276 \\
4 & Narkotika & 41 & 184,868 \\
5 & Hasil tembakau & 477 & 3,151 \\
6 & MMEA** & 190 & 27,569 \\
7 & Barang lainnya & 382 & 16,015 \\
& Total .... & 2,109 & 253,936 \\
\hline
\end{tabular}

Tabel 4. Kerugian Negara yang Disebabkan oleh Penyelundupan ahun 2009

\begin{tabular}{clrr} 
No. & \multicolumn{1}{c}{ Jenis Kasus } & $\begin{array}{c}\text { Jumlah } \\
\text { Kasus }\end{array}$ & \multicolumn{2}{c}{$\begin{array}{c}\text { Kerugian Negara } \\
\text { (dalam Milliar Rp) }\end{array}$} \\
1 & Tekstil dan produk tekstil & 56 & 43,314 \\
2 & Handphone dan aksesoris & 141 & 74,09 \\
3 & Barang lartas* & 411 & 6,671 \\
4 & Narkotika & 79 & 333,709 \\
5 & Hasil tembakau & 592 & 62,844 \\
6 & MMEA** & 310 & 69,905 \\
7 & Barang lainnya & 504 & 7,281 \\
& Total .... & 2,093 & 523,742 \\
\hline
\end{tabular}

Sumber: diolah dari berbagai sumber.

Keterangan:

*Lartas : pelarangan dan pembatasan

**MMEA : Minuman Mengandung Etil Alkohol

\section{METODE}

Kajian dilakukan menggunakan metodologi kualitatif dengan pendekatan normatif dan studi kepustakaan yang bersumber dari, peraturan perundang-undangan, buku, dan artikel jurnal ilmiah.

\section{HASIL DAN PEMBAHASAN}

Dilahirkannya UU Kepabeanan merupakan suatu perwujudan dari peraturan perundang-undangan yang berasaskan Pancasila (Tanya, 2015:8) dan UUD 1945, yang di dalamnya terkandung asas keadilan (Sulistiyono, 2007:21), menjunjung tinggi hak setiap anggota masyarakat, dan menempatkan kewajiban pabean sebagai kewajiban kenegaraan yang mencerminkan peran serta anggota masyarakat dalam menghimpun dana melalui pembayaran bea masuk, maka peraturan perundangundangan kepabeanan sebagai bagian dari hukum fiskal harus dapat menjamin perlindungan kepentingan masyarakat, kelancaran arus barang, orang, dan dokumen, penerimaan bea masuk yang optimal, dan dapat menciptakan iklim usaha yang dapat lebih mendorong laju pembangunan nasional (Lindawati).

Pasar gelap maupun pasar abu-abu sangat erat kaitannya dengan penyelundupan. Penyelundupan tanpa tujuan kecuali untuk memperoleh uang dalam jumlah besar yang merupakan jenis tindakan kriminal. Benar, barang selundupan bisa dijual lebih murah dan karena itu menguntungkan konsumen. Tapi keuntungan konsumen ini merugikan setidaknya tiga pihak: negara, produsen barang serupa, dan pedagang yang jujur. Karena itu dalam jangka waktu tertentu, penyelundupan akan menghancurkan industri produk yang diselundupkan, menjadikan pemerintah kehilangan pendapatan yang mestinya harus 
dikembalikan kepada rakyat itupun kalau tidak dikorupsi (Widayanto, 2011:45).

Adapun aspek-aspek yang menjadi perhatian dari UU Kepabeanan adalah:

a. keadilan, sehingga kewajiban pabean hanya dibebankan kepada masyarakat yang melakukan kegiatan kepabeanan dan terhadap mereka diperlakukan sama dalam hal dan kondisi yang sama;

b. pemberian insentif yang akan memberikan manfaat pertumbuhan perekonomian nasional yang antara lain berupa fasilitas tempat penimbunan berikat, pembebasan bea masuk atas impor mesin dan bahan baku dalam rangka ekspor, dan pemberian persetujuan impor barang sebelum pelunasan bea masuk dilakukan;

c. netralitas dalam pemungutan bea masuk, sehingga distorsi yang mengganggu perekonomian nasional dapat dihindari;

d. kelayakan administrasi, yaitu pelaksanaan administrasi kepabeanan dapat dilaksanakan lebih tertib, terkendali, sederhana, dan mudah dipahami oleh anggota masyarakat sehingga tidak terjadi duplikasi. Oleh karena itu biaya administrasi dapat ditekan serendah mungkin;

e. kepentingan penerimaan negara, dalam arti ketentuan dalam Undang-undang ini telah memperhatikan segi-segi stabilitas, potensial, dan fleksibilitas dari penerimaan, sehingga dapat menjamin peningkatan penerimaan negara, dan dapat mengantisipasi kebutuhan peningkatan pembiayaan pembangunan nasional;

f. penerapan pengawasan dan sanksi dalam upaya agar ketentuan yang diatur dalam undang-undang ini ditaati;

g. Wawasan Nusantara, sehingga ketentuan dalam Undang-undang ini diberlakukan di daerah pabean yang meliputi wilayah negara kesatuan Republik Indonesia, dimana Indonesia mempunyai kedaulatan dan hak berdaulat yaitu, diperairan pedalaman, perairan nusantara, laut wilayah, zona tambahan, zona ekonomi eksklusif, landasan kontinen, dan selat yang digunakan untuk pelayaran internasional;

h. praktek kepabeanan internasional sebagaimana diatur dalam persetujuan perdagangan internasional (Widayanto, 2011:45).

Selain itu juga di dunia internasional bangsa Indonesia terkenal sebagai salah satu negara yang memiliki etika yang baik, rakyatnya yang ramah tamah, sopan santun yang dijunjung tinggi nilai. Pancasila memegang peranan besar dalam membentuk pola pikir bangsa ini sehingga bangsa ini dapat dihargai sebagai salah satu bangsa yang beradab di dunia.

Dalam Pancasila terkandung nilai-nilai yang luhur. Semangat menyelenggarakan segala yang benar, adil, dan baik (sari sila pertama) menjadi "acuan moral/nilai" bagi empat sila yang lain: kemanusiaan (sila kedua), kebangsaan (sila ketiga), kenegaraan (sila keempat), dan kemasyarakatan (sila kelima). Artinya, fundamen moral dalam Sila Ketuhanan berupa semangat menyelenggarakan segala yang benar, adil, dan baik itu, menjiwai upaya mengelola semua masalah yang ada dalam empat sila yang lain itu (Tanya, 2015:11).

Seokarno dengan tegas mengatakan bahwa teras Pancasila adalah gotong royong. Dimana gotong royong merupakan prinsip sentral terhadap sila pertama yang merupakan jalan gotong-royong antara semua kelompok agama/kepercayaan; sila kedua adalah jalan gotong-royong antar sesama manusia (atas dasar spirit mulia sila pertama) untuk menegakkan kemanusiaan; sila ketiga adalah jalan gotong-royong antar sesama anak bangsa (atas spirit mulia sila pertama dan keharusan normatif sila kedua) untuk menjaga persatuan dalam rumah Indonesia; sila keempat adalah jalan gotongroyong antar semua penyelenggara negara (atas dasar spirit mulia sila pertama, keharusan normatif sila kedua, dan semangat persatuan sila ketiga) untuk 
bersama-sama (secara hikmat-bijaksana dan musyawarah-mufakat) mengelola negara untuk melayani kepentingan rakyat sebagai pemilikmtumah Indonesia; dan sila kelima adalah jalan gotong-royong antar sesama warga masyarakat: kaya dan miskin, kuat dan lemah (atas dasar spirit mulia sila pertama, keharusan normatif sila kedua, semangat persatuan sila ketiga, dan misi luhur sila keempat) untuk saling berbagi dan saling menatang merealisasikan/mewujudkan keadilan sosial bagi seluruh rakyat yang menghuni rumah Indonesai (Tanya, 2015:4).

Pancasila merupakan kristalisasi perasaan-perasaan, keinginan-keinginan, dan isi jiwa bangsa Indonesia turuntemurun. Ia telah lama terkandung dalam kalbu rakyat Indonesia (Tanya, 2015:31).

Hingga Oktober 2015 Dirjen Bea dan Cukai mencatat khusus untuk kasus penyelundupan barang elektronik meningkat sebanyak 33 kasus. Pada tahun 2014 tercatat 96 kasus, negara dirugikan sebesar 41,6 Miliar. Sedangkan hingga Oktober 2015 tercatat 129 kasus, negara dirugikan sebesar 74,6 Miliar (Rochimawati dan Budiawati).

Perbuatan penyelundupan ekspor atau impor jelas merugikan keuangan negara (Prawita, 2015:26) dan akan membuat keuangan negara semakin terpuruk. Menurut penulis perbuatan penyelundupan tersebut merupakan kegiatan bisnis para pengusaha yang tidak mengabdi pada kepentingan nasional dan tidak memiliki etika bisnis (Sulistiyono, 2009:110). Perbuatan penyelundupan ini penulis anggap tidak memiliki etika bisnis, karena para pengusaha telah menggunakan cara yang tidak benar untuk memajukan bisnisnya dengan bersikap tidak jujur dengan membohongi aparat pemerintah.

Selain itu juga masih ada oknum yang ikut berperan dalam terjadinya tindak pidana di bidang kepabeanan tersebut. Setidaknya ada tiga pihak yang bekerja sama, yang pertama importir, yang kedua tentu saja pengusaha pengurusan jasa kepabeanan, dan yang ketiga oknum (Yulika dan Rahmat).

Sila kelima Pancasila merupakan doktrin Indonesia tentang demokrasi ekonomi, yakni keharusan mewujudkan keadilan bagi seluruh rakyat Indonesia. Doktrin demokrasi ekonomi ini menjadi landasan politik negara dan hukum dalam merawat kehidupan bermasyarakat.

\section{SIMPULAN DAN SARAN}

\section{Simpulan}

Masih tingginya angka penyelundupan yang tejadi di Indonesia, menurut penulis merupakan suatu gambaran bahwa bidang ekonomi di Indonesia masih miskin nilai sehingga harus ditata dengan politik nilai keadilan sosial. Dimana seharusnya pengusaha dalam menjalankan bisnisnya ataupun para aparat dalam menjalankan tugasnya berpedoman pada nilai keadilan sosial. Apabila nilai keadilan sosial telah menjadi karakter bagi mereka, maka kecurangan (fraud) dalam kegiatan ekspor dan impor tidak akan terjadi. Sehingga dalam setiap kegiatan ekspor dan impor, baik pengusaha maupun aparat akan bersikap dan bertindak berdasarkan nilai keadilan sosial tersebut.

\section{Saran}

Masih tingginya angka penyelundupan di Indonesia merupakan suatu gambaran bahwa bidang ekonomi di Indonesia masih miskin nilai sehingga harus ditata dengan politik nilai keadilan sosial. Dalam hal ini hukum harus berusaha untuk menanamkan pemahaman pada pengusaha dan aparat akan nilai keadilan sosial. Dengan menjadikan nilai keadilan sosial sebagai karakter bagi mereka, maka kecurangan (fraud) dalam kegiatan ekspor dan impor tidak akan terjadi. Hukum juga harus bisa memastikan bahwa negara tidak menipu rakyatnya, tidak mencuri harta rakyat, tidak memanipulasi kepentingan rakyat. Dengan demikian, negara diharapkan mampu 
Citizenship Jurnal Pendidikan Pancasila dan Kewarganegaraan Vol 5 No 1 April 2o17, hal 32-41 Avaliable online at : http://e-journal.unipma.ac.id/index.php/citizenship p-ISSN: 2302-433Xp e-ISSN 2579-5740

menjadi pengelola keadilan sosial bagi seluruh rakyat Indonesia.

\section{DAFTAR PUSTAKA}

Alicezah, Globalisasi dalam Bidang Ekonomi, https://alicezah.files.wordpress.com/2 008/06/globalisasi.pdf, diakses 11 November 2015.

Adi Sulistiyono, Pembangunan Hukum Ekonomi untuk Mendukung Pencapaian Visi Indonesia 2030, Pidato Pengukuhan Guru Besar Hukum Ekonomi pada Fakultas Hukum Universitas Sebelas Maret, Disampaikan dalam Sidang Senat Terbuka Universitas Sebelas Maret pada tanggal 17 Nopember 2007.

sebagai Panglima, Masmedia Buana Pustaka, Sidoarjo, 2009.

Bayu Purnomo Setyawan, Sistem Pemidanaan Perundang-undangan dalam Menanggulangi Tindak Pidana Peyelundupan Barang Ekspor Impor di Indonesia, Tesis, Universitas Sebelas Maret, 2014.

Bernard L. Tanya, Pancasila Bingkai Hukum Indonesia, Genta Publishing, Yogyakarta, 2015.

Ke-Indonesia-an, Disampaikan dalam Forum Diskusi Dosen UPT-MKU Universitas Sebelas Maret, Surakarta tanggal 21 Mei 2015.

Deliarnov, Ekonomi Politik, Erlangga, Jakarta, 2006.

Desi Prawita, Presiden Joko Widodo Senang Perintahnya Segera Ditindaklanjuti Bea Cukai Terkait Pengawasan Impor
Ilegal, Warta Bea Cukai, Volume 47, Nomor 11, November 2015.

Eddhi Sutarto, Efektivitas UU No. 10 Tahun 1995 tentang Kepabeanan dalam Menegakkan Fungsi Kepabeanan di Indonesia, Tesis, Universitas Diponegoro, 1999.

Rekonstruksi Hukum Pabean Indonesia, Erlangga, Jakarta, 2010.

Flora Susan Nongsina dan Pos M. Hutabarat, Pengaruh Kebijakan Liberalisasi Perdagangan Terhadap Laju Pertumbuhan Ekspor-Impor Indonesia, http://Mukhyi.Staff.Gunadarma.Ac.Id/ Downloads/Files/9106/Pengaruh+Keb ijakan+Liberalisasi+Perdagangan+Ter hadap+Laju+Pertumbuhan+EksporImpor+Indonesia.pdf., diakses 28 Januari 2016.

Latif Adam dan Maxensius Tri Sambodo, Investasi dan Perdagangan Luar Negeri: Dinamika Globalisasi dan Perannya dalam Pertumbuhan Ekonomi, Jurnal Ekonomi dan Pembangunan, Vol. XVI No. 2, LIPI Press, Jakarta, 2008.

Leden Marpaung, 1991, Tindak Pidana Penyelundupan Masalah dan Pemecahan, Gramedia Pustaka Utama, Jakarta.

Nila Chrisna Yulika dan Agus Rahmat, Impor Ilegal, Jokowi Tuding Ada Oknum di Bea Cukai, http://bisnis.news.viva.co.id/news/ read/686119-impor-ilegal--jokowituding-ada-oknum-di-bea-cukai, diakses 15 Desember 2015.

Ricardo Simanjuntak, Asas-asas Utama Hukum Kontrak dalam Kontrak Dagang Internasional: Sebuah 
Citizenship Jurnal Pendidikan Pancasila dan Kewarganegaraan Vol 5 No 1 April 2017, hal 32-41 Avaliable online at : http://e-journal.unipma.ac.id/index.php/citizenship p-ISSN: 2302-433Xp e-ISSN 2579-5740

Tinjauan Hukum, Jurnal Hukum Bisnis, Vol. 27 No. 4, Yayasan Pengembangan Hukum Bisnis, Jakarta, 2008.

Rita Dwi Lindawati, Bahan Ajar Undangundang Kepabeanan, Program Diploma III Keuangan Spesialisasi Kepabeanan dan Cukai, STAN, http://akademik.stan.ac.id/vclass_repo sitory/2012-09-

11_20112_80000016_UU\%20Kepabe anan.pdf, diakses 22 November 2015.

Rochimawati dan Arie Dwi Budiawati, Penyelundupan Barang Elektronik Meningkat, http://bisnis.news.viva.co.id/news/ read/692183-penyelundupanbarang-elektronik-meningkat, diakses 18 November 2015.

Rowland, B.F. Pasaribu, Globalisasi dan Pembangunan Ekonomi Indonesia, https://ml.scribd.com/doc/171662067/ 14-Globalisasi-dan-PembangunanEkonomi-Indonesia, diakses 15 November 2015.
Saufnir Chibro, Pengaruh Tindak Pidana Penyelundupan Terhadap Pembangunan, Cetakan Ketiga, Sinar Grafika, Jakarta, 1992.

Sulistyo Widayanto, Prosedur Notifikasi WTO untuk Transparansi Kebijkan Impor Terkait Bidang Perdaganagan, Kewajiban Pokok Indonesia sebagai Anggota Organisasi Perdagangan Dunia (World Trade Organization), Jakarta, Direktorat Kerja Sama Multilateral Direktorat Jenderal Kerja Sama Perdagangan Internasional Kementrian Perdagangan Republik Indonesia, 2011.

Syarip Hidaya, Pengaruh Globalisasi Ekonomi dan Hukum Ekonomi Internasional Dalam Pembangunan Hukum Ekonomi di Indonesia, http://ejournal.narotama.ac.id/files/pen garuh_globalisasi_ekonomi.pdf, diakses 15 November 2015.

Wikipedia, Neraca perdagangan, https://id.wikipedia.org/wiki/Nera ca_perdagangan\#cite_note-1, diakses 28 Januari 2016. 